\title{
Towards a Blending-Based Approach to Early Christian Characters: Nicodemus as a Test Case
}

\author{
Michael R. Whitenton \\ Baylor University, Waco, TX, USA \\ mike_whitenton@baylor.edu
}

\begin{abstract}
This article presents a blending-based approach to characters in early Christian narratives. Even cognitive approaches to complex characters (including my previous work) tend to frame character development as a primarily linear unidirectional process. However, the human mind integrates incoming information through processes that are more recursive than linear and more synergistic than summative. I propose that Cognitive Blending Theory, pioneered by Gilles Fauconnier \& Mark Turner, provides a heuristic approach that better accounts for the complexity of cognitive information processing. First, I articulate a blending-based approach to ancient characters. Next, I show the validity of such an approach by modeling the blends for each of Nicodemus's appearances in John's gospel, focusing on the novel insights only available through blending. As will become apparent, these blends are interrelated, building upon and challenging one another on the path toward a complete characterization of "Nicodemus" across John's gospel. I conclude with brief reflections on the future prospects of blending-based character studies.
\end{abstract}

\section{Keywords}

conceptual blending - cognitive approach - character development - information processing - Gospel of John - Nicodemus 


\section{Introductory Remarks*}

Until recently, modern scholars of ancient narrative often treat characters like mere plot functionaries-one-dimensional pawns in service of plot progression. ${ }^{1}$ While traditional literary readings have maintained this decidedly text-based focus, integrating cognitive studies into the field of narratology introduced new questions and offered novel insights for "reading" characters in the minds of readers. ${ }^{2}$ Indeed, my work takes part in the ongoing "cognitive boom" in the study of the New Testament and other early Christian literature. ${ }^{3}$ In Configuring Nicodemus: An Interdisciplinary Approach to Complex Characterization (Bloomsbury 2019), I proposed a dynamic approach to complex characterization based on Ralf Schneider's cognitive theory of literary

* I wish to thank the editors of this special issue, Jan Rüggemeier and Elizabeth Shively, both for the invitation and their critical eye. This article is far stronger because of their constructive criticism and that of the anonymous reviewer. Thanks also to Ralf Schneider, my respondent, whose work has been so formative for my own integration of the humanities and cognitive sciences. Finally, a special thanks to my writing group at Baylor, especially Paul Carron, AnneMarie Schultz \& Lenore Wright, and to Rachel Whitenton, for their insightful comments on earlier drafts. Responsibility for all remaining shortcomings must surely be mine alone.

1 For a literature review characterization in the New Testament, see C. Bennema, $A$ Theory of Character in New Testament Narrative (Minneapolis: Fortress, 2014); M.R. Whitenton, Configuring Nicodemus: An Interdisciplinary Approach to Complex Characterization (LNTS, 549; London: T\&T Clark, 2019). Cf. C. Gill, "The Question of Character-Development: Plutarch and Tacitus," ClQ 33 (1983), pp. 469-487.

2 See, e.g., U. Margolin, "Collective Perspective, Individual Perspective, and the Speaker in Between: On 'We' Literary Narratives," in W.V. Peer and S.B. Chatman eds., New Perspectives on Narrative Perspective (New York: SUNY Press, 2001); J. Culpeper, "Reflections on a Cognitive Stylistic Approach to Characterisation," in G. Brône and J. Vandaele eds., Cognitive Poetics: Goals, Gains and Gaps (Berlin: De Gruyter, 2009). See further, J. Culpeper, "Inferring Character from Texts: Attribution Theory and Foregrounding theory," Poetics 23 (1996), pp. 335-361; J. Culpeper, Language and Characterisation: People in Plays and Other Texts (London: Routledge, 2001); J. Gavins and G. Steen eds., Cognitive Poetics in Practice (London: Routledge, 2003); D. Herman, Storytelling and the Sciences of Mind (Cambridge, MA: MIT Press, 2013). See also, R. Schneider, "Toward a Cognitive Theory of Literary Character: The Dynamics of MentalModel Construction," Style 35 (2001), pp. 607-640. See also, M. Bortolussi and P. Dixon, Psychonarratology: Foundations for the Empirical Study of Literary Response (Cambridge: Cambridge University Press, 2003).

3 See, e.g., M.R. Whitenton, "The Dissembler of John 3: A Cognitive and Rhetorical Approach to the Characterization of Nicodemus," JBL 135 (2016), pp. 141-158; M.R. Whitenton, "Feeling the Silence: A Moment-by-Moment Account of Emotions at the End of Mark (16:1-8)," 79 (2016), pp. 272-289; M.R. Whitenton, "Tasting the Kingdom: Wine-Drinking and Audience Inference in Mark 15.36," JSNT 40 (2018), pp. 403-423; M.R. Whitenton, Hearing Kyriotic Sonship: A Cognitive and Rhetorical Approach to the Characterization of Mark's Jesus (BibInt Series, 148; Leiden: Brill, 2017); Whitenton, Configuring Nicodemus. 
characters. ${ }^{4}$ Schneider argued that the mind constructs mental models of characters by responding to incoming textual information in ways that oscillate between categorization- and personalization-based pathways. Categorization prioritizes the use of cognitive frames ${ }^{5}$ (including character types), organized bundles of knowledge based on cultural norms, experience, and other prior knowledge to make inferences about a character. ${ }^{6}$ For example, in the United States, a woman carrying a package and wearing a brown uniform approaches your front door will probably activate your UPS WORKER frame. If textual cues do not activate cognitive frames in the readers'/hearers' mental lexicons, then Schneider argued, the mind tends toward "personalization," which relies more on a character's individuating actions and behavior, but not to the exclusion of a reader's personal experiences. ${ }^{7}$ Note that even in personalization, a reader must rely on category-based processes. ${ }^{8}$ All things being equal, the human brain prefers categorization- to personalization-based pathways. ${ }^{9}$ When a reader first encounters a character, they form an initial categorization of the person based on available frames. If additional incoming information supports the initial

4 Schneider, pp. 6o8, 627. See further, R. Schneider, Grundriss zur kognitiven Theorie der Figurenrezeption am Beispiel des viktorianischen Romans (ZAA Studies, 9; Tübingen: Stauffenburg, 200o). On empathy and its role in the narrative experience, see E.S. Tan, Emotion and the Structure of Narrative Film: Film As An Emotion Machine (New York: Routledge, 1995), pp. 15-40, 153-194; S. Keen, Empathy and the Novel (Oxford: Oxford University Press, 2007), pp. 65-10o. Cf. E.S. Tan, "Film-Induced Affect as a Witness Emotion," Poetics 23 (1994), pp. 7-32. For the details on the model I proposed, see Whitenton, Configuring Nicodemus, pp. 11-54.

5 The important question of whether a character type is a frame or simply organized by one lies beyond the scope of this essay. For Faucounnier and Turner, "frames and characters are interlocking aspects of human reality," which each mutually converge on our understanding of the other (The Way We Think: Conceptual Blending and The Mind's Hidden Complexities [New York: Basic Books, 2002], pp. 252-253). For the sake of this essay, character types can either function as an input space or a frame, depending on their positioning within the blend.

6 Some scholars refer to categorization as a top-down approach because textual cues activate frames from readers'/hearers' mental lexicons which then allow readers to work deductively with incoming information. See further, Schneider, "Toward a Cognitive Theory," pp. 626-627. Cf. P.C. Hogan, Cognitive Science, Literature, and the Arts: A Guide for Humanists (New York: Routledge, 2003), pp. $4^{2-58}$. By contrast, personalization is more of a "bottom-up" process because the reader constructs the character more inductively.

7 Schneider, "Toward a Cognitive Theory," p. 627.

8 As Schneider ("Toward a Cognitive Theory") points out, "personalization can occur whenever the reader does not categorize a character, i.e., when he or she is not able or willing to apply stored structures of knowledge for ad hoc impression formation. Even in that case the mental apparatus cannot entirely do without recourse to top-down processing, but [...] the structures of knowledge that come into play" derive from specific memories of actual properties of real people (p. 625).

9 Schneider, “Toward a Cognitive Theory," p. 617. 
characterization, confirmatory categorization occurs. Recategorization occurs if incoming information more strongly activates a different, competing frame. In the relatively rare event that incoming information does not strongly activate any frame, the reader cobbles together a mental model of a character in an attribute-by-attribute fashion with only minimal recourse to any category through piecemeal integration (or personalization). ${ }^{10}$

Using the framework outlined above, I argued that Nicodemus probably developed from dissembler to disciple across his three appearances in John's gospel, in terms of ancient audience reception. When ancient audiences heard John's gospel read aloud, I argued, they would likely initially categorize Nicodemus as a dissembler, who loved the darkness too much to come to God's light, rather than someone who merely misunderstands Jesus's message (John 3:1-21). ${ }^{11}$ Nicodemus's subsequent defense of Jesus would likely trigger elements of both confirmatory categorization and personalization (7:50-51). For example, Nicodemus still dissembles with a clever question (cf. 7:51), which confirms the initial categorization of DISSEM BLER. However, Nicodemus dissembles in a way that his fellow Pharisees interpret as a step toward allegiance to Jesus (which personalizes his character) (cf. 7:52). Ultimately, I argued that Nicodemus's public support for and service to Jesus after his death would lead attentive readers to recategorise him as one of Jesus's disciples (cf. 19:38-42).12

In this article, I extend my previous work by offering a blending-based theory and model for understanding and representing the dynamic processing theory of characterization described above. ${ }^{13}$ First, I adapt blending theory, primarily as represented in the work of Giles Fauccounier, Ralf Schneider, and

10 Adapted from S.T. Fiske and S.L. Neuberg, "A Continuum of Impression Formation, From Category-Based to Individuating Processes: Influences of Information and Motivation on Attention and Interpretation," in M.P. Zanna ed., Advances in Experimental Social Psychology (New York: Academic Press, 199o). For Schneider's map of these "dynamics of mental model construction in character reception," see "Toward a Cognitive Theory," p. 627.

11 On which, see Whitenton, Configuring Nicodemus, pp. 79-106. The Dissembler character type was ubiquitous in antiquity and, Nicodemus's fawning praise, unexplained befuddlement, and connection to the duplicitous Pharisees would probably have activated the Dissembler character type. On the DISSEMBLER and other relevant character types, see Whitenton, Configuring Nicodemus, pp. $55^{-78}$. The literary context similarly suggests that audience members treat Nicodemus as one of the anthropoi whom Jesus did not trust (cf. 2.23-25). Jesus's own rhetoric supports such a conclusion, as well (cf. Quintilian, Inst. 9.2.68-70). On which, see Whitenton, Configuring Nicodemus, pp. 107-118.

13 Following Fauconnier and Turner, I understand mental spaces as "small conceptual packets constructed as we think and talk, for purposes of local understanding and action. Mental spaces are very partial assemblies containing elements, and structured by frames and cognitive models. They are interconnected, and can be modified as thought and discourse unfold." See G. Fauconnier and M. Turner, "Conceptual Integration Networks," Cognitive Science 22 (1998), pp. 133-87 (137). 
Mark Turner, to explain the dynamic processes of characterization. From this perspective, dynamic processing becomes a recursive two-stage blend that ultimately yields a mental model of a particular character in ancient literature: (1) the initial blend that takes place during a character's first appearance and (2) the subsequent integrations of later appearances with that initial blend. ${ }^{14}$ I begin with the initial blend of Nicodemus in John 3 with relevant character types ("Nic A"). Next, I detail a blend of Nic A with Nicodemus's appearance in John 7 ("Nic B"). I conclude by blending Nic B with Nicodemus's last appearance (John 19) ("Nic C"). The progression from Nic A to Nic C is recursive, synergistic, and represents a holistic characterization of Nicodemus within John's narrative world. Not only does such an approach highlight significant methodological possibilities regarding the integration of the cognitive sciences with more traditional literary approaches, but it also prompts us to think of one of John's most essential and peculiar characters in ways that ground us to the experience of actual readers.

\section{An Overview of Blending Theory}

Nearly twenty years ago, Gilles Fauconnier and Mark Turner argued that a phenomenon known as "blending" accounts for several processes that influence perceptions of identity, both of self and others. ${ }^{15}$ "Blending theory," also called "conceptual integration," explains the mental realm of sense-making as a mixture of incoming information with different "mental spaces." These mental spaces include related frames (such as the MAD SCIENTIST, the PROBLEM CHILD, the FEMME FATALE, the LIAR, the DAMSEL IN DISTRESS, the HOSPITABLE HOST, etc.) and other background information. The end product of this mental process of blending is more than a mere summation of the individual parts, often reflecting elements that move beyond the sum of their parts. While conceptual metaphor attracted most of Blending theory's early attention, the theory claims to reflect the entirety of human cognition, from the origins of language to fictive realities to corporations to notions of the self, others, and even literary characters. ${ }^{16}$

14 On which, see R. Schneider, "Blending and the Study of Narrative: An Introduction," in R. Schneider and M. Hartner eds., Blending and the Study of Narrative: Approaches and Applications (Berlin: De Gruyter, 2012), pp. 16-17. These two blending subtypes are not necessarily mutually exclusive.

15 Fauconnier and Turner, The Way We Think, pp. 249-267.

16 Fauconnier and Turner, The Way We Think, p. 40. 
Generic Space

(facilitates correspondence between input spaces)

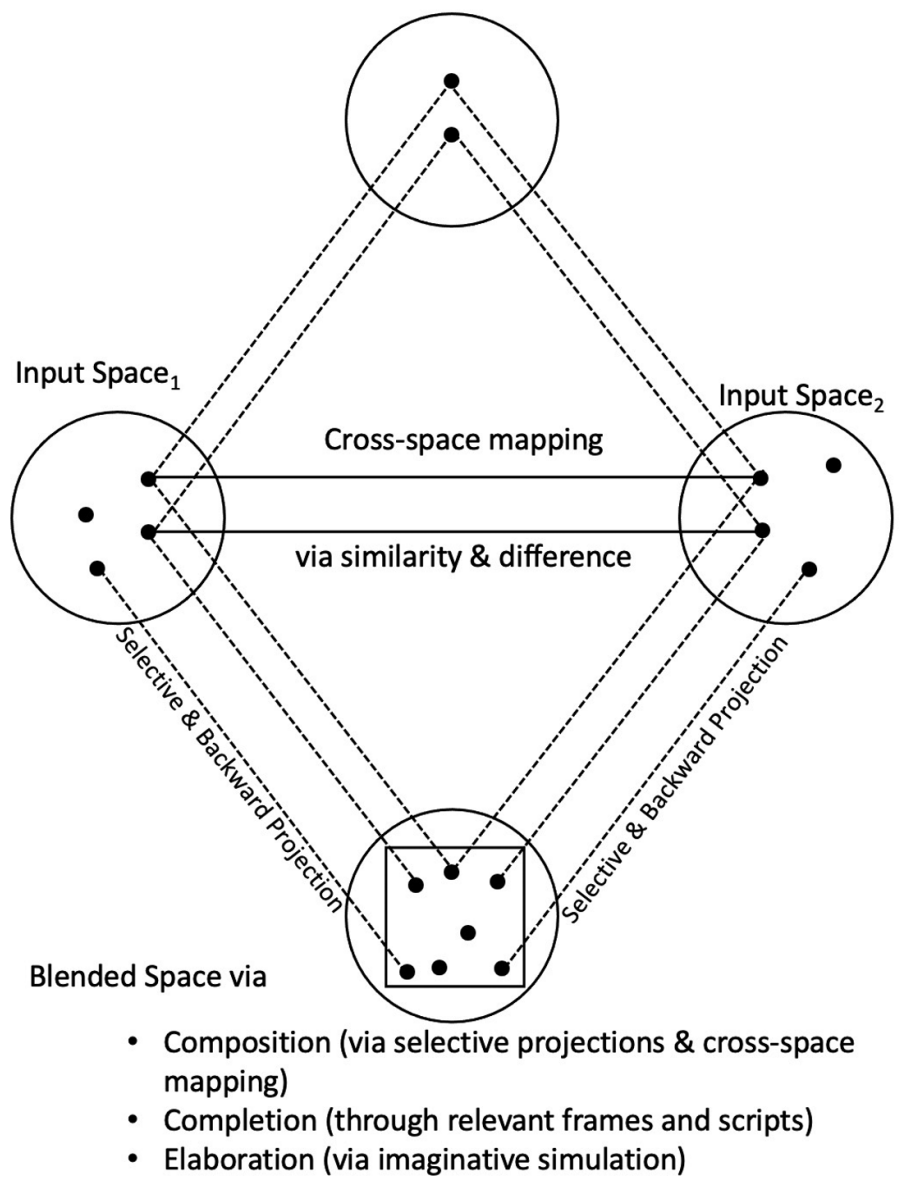

FIGURE $1 \quad$ Basic Blending Model ${ }^{17}$

Figure 1 below shows a basic blending model, while Figure 2 provides an oftused example blend.

Blending models must have at least four mental spaces. Two input spaces, linked by a generic space, selectively integrated to form an emergent structure called the blended space, an imaginative equilibrium of the input spaces that goes beyond a simple summative union to form genuinely new meaning

17 Reproduced and adapted from Fauconnier and Turner, The Way We Think, p. 46. 


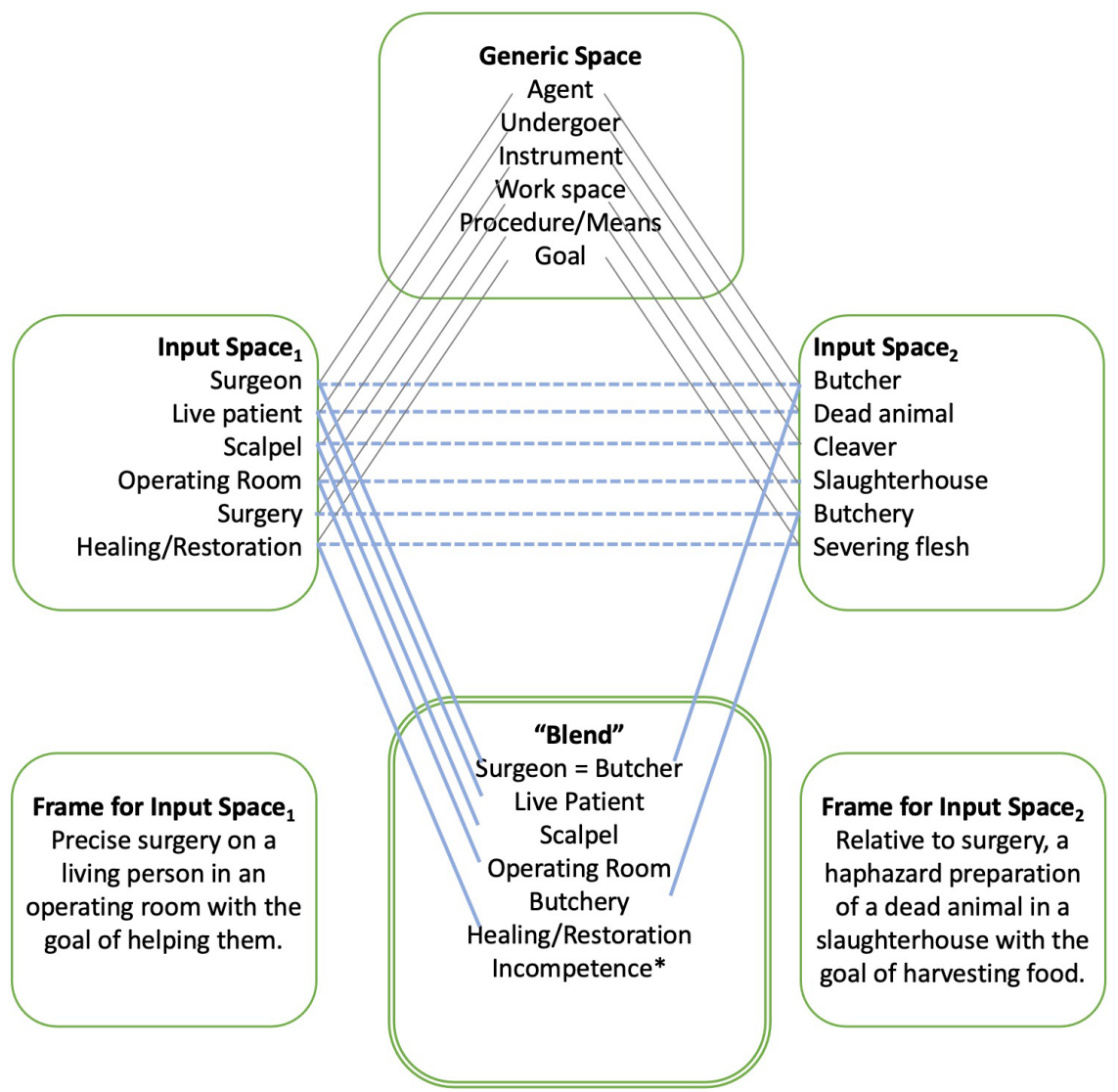

FIGURE 2 Blend for "That surgeon is a butcher!" (here and throughout, an asterisk [*] indicates emergent structures)

(sometimes called "emergent structure"). ${ }^{18}$ Corresponding elements among input spaces may project onto the blended space (selective projection), even as the blended space can project backward, challenging or reinforcing the content of the input spaces (backward projection)..$^{19}$ In addition, the input spaces can and do interact based on similarities and differences through crossspace mapping. The square within the blended space represents the "emergent structure," which is the product of (1) the composition based on (selective and backward) projections from the inputs, (2) completion through independently recruited frames and scripts from prior knowledge, and (3) elaboration, also

18 By "new meaning" and "emergent structure," I refer to emergent meaning within the blended space not present in any input space.

19 See Figure 2 below for an example. 
called "running the blend," in which the mind runs imaginative simulations of the products of completion based on the principles established by the blend. ${ }^{20}$

A classic example from the study of conceptual metaphors illustrates how blending works in practice: "That surgeon is a butcher!"21

In Figure 2 above, notice that cross-space mapping creates meaning based on similarities and differences between the corresponding aspects linked through the generic space (composition). In this case, Table 1 shows how the elements associated with "butchery" map onto those of "surgery":

Cross-space composition, however, does not alone explain the emergent structure in the blended space (incompetence). As we organize the blended space through completion, we integrate the corresponding elements according to associated frames (including the connotations of those frames). In this case, the dissonance between the connotations of surgery and butchery account for the emergent material: SURGERY conjures up images of a clean operating room, sterile specialized equipment (e.g., scalpel) used to open the body, and careful methods for closing the surgical openings after the procedure with the ultimate aims of healing or restoration of a living human body. By contrast, BUTCHERY calls to mind the non-sterile, however skilled, severing of dead animal flesh, with larger cutting implements, and no concern for closing the dead (and usually skinned) animal because the goal is harvesting food, not healing. In elaboration ("running the blend"), we simulate the completion for "that

TABLE 1 Mappings for THAT SURGEON IS A BUTCHER 22

\begin{tabular}{lll}
\hline Source: BUTCHER & Mappings & Target: SURGEON \\
\hline Butcher & $\rightarrow$ & Surgeon \\
Dead animal & $\rightarrow$ & Live patient \\
Cleaver & $\rightarrow$ & Scalpel \\
Slaughterhouse & $\rightarrow$ & Operating Room \\
Butchery & $\rightarrow$ & Surgery \\
Severing flesh & $\rightarrow$ & Healing/Restoration
\end{tabular}

20 M. Turner, "Conceptual Integration," in D. Geeraerts and H. Cuyckens eds., The Oxford Handbook of Cognitive Linguistics (Oxford: Oxford University Press, 2010), pp. 379-380. Cf. Fauconnier and Turner, The Way We Think, pp. 39-58.

21 The first extensive study of conceptual metaphors from a blending perspective was G. Lakoff and M. Johnson, Metaphors We Live By (Chicago: University of Chicago Press, 1980).

22 Adapted from V. Evans and M.J. Green, Cognitive Linguistics: An Introduction (Edinburgh: Edinburgh University Press, 2006), pp. 401-402. 
surgeon is a butcher!" based on its internal logic. You want a skilled butcher if you are looking to harvest an animal, but a skilled butcher does not necessarily make a skilled surgeon. Likening a surgeon to a butcher implies the surgeon abandons the norms associated with SURGERY for those linked to BUTCHERY. People would typically classify a surgeon who acts like a butcher as incompetent qua surgeon.

If this is how Blending theory works with metaphors, how might it apply to characterization more broadly?

\section{Blending and Characterization}

Blending theory holds significant potential to explain the interplay between categorization (based on frames, scripts, and other prior knowledge) and personalization (the individuating actions and speech of a character) that go into mentally modeling a character's first appearance, as well as integrating that character's subsequent appearances. ${ }^{23}$ Schneider has suggested two kinds of blending vis-à-vis characters: (1) those used to construe characters in their narrative worlds (inner-fictional blends) and (2) those that blend character and reader (reader-character blends). In this context, I am only interested in the former. ${ }^{24}$ Inner-fictional blends help readers experience "the identity formation processes of the character, using as input spaces different manifestations of that character at different points in time and in different places and compress them."25 These blends can take at least two critical forms: (1) blending a character and a frame (such as a character type), and (2) blending a character

23 See Schneider, "Blending," pp. 15-17. While blending has not received much attention within the study of early Christian narrative characters, this is beginning to change. See, e.g., H. Lundhaug, Images of Rebirth: Cognitive Poetics and Transformational Soteriology in the Gospel of Philip and the Exegesis on the Soul (N HMS, 71; Leiden: Brill, 2010); J. Rüggemeier, Poetik der markinischen Christologie: Eine kognitiv-narratologische Exegese (wUNT 2, 458; Tübingen: Mohr Siebeck, 2017), pp. 7-102; K.M. Hartvigsen, Aseneth's Transformation (DCLS, 24; Berlin: De Gruyter, 2018).

24 While this essay focuses on inner-fictional blends, I plan to work with reader-character blends in a later project.

25 Schneider, "Blending," p. 16. Inner-fictional blends can occur through explicit manifestations of a character, or they can arise implicitly through tacit comparisons between characters in similar situations that behave differently. They also occur between interacting character perspectives. M. Hartner, "Constructing Literary Character and Perspective: An Approach from Psychology and Blending Theory," in R. Schneider and M. Hartner eds., Blending and the Study of Narrative: Approaches and Applications (Berlin: De Gruyter, 2012), pp. 85-120. See also, M. Hartner, Perspektivische Interaktion im Roman: Kognition, Rezeption, Interpretation (Berlin: De Gruyter, 2012). 
and a character (including subsequent appearances of the same character). ${ }^{26}$ The first type of blend (between a character and a frame) relates most directly to categorization-based aspects of dynamic processing because readers often work from social categories and character types, from folk psychology and/or in literature, which "must be blended with the space referring to the particular character presented in the text."27 The second type of blend (between initial and subsequent character appearances) represents categorization and personalization tendencies in the dynamic processing model. This second type of blend is where we begin to appreciate the complexity of characterization from a cognitive perspective (see Figure 4 below). ${ }^{28}$

Figure 3 below shows one way to represent a blend between a character and character type(s):

Selective projection fueled by similarities and differences between input spaces via cross-space mapping populates the blended space (composition). Once composed, pre-existing frames (including type-scenes and narrative episodes) organize the blended space (completion), which is ultimately simulated imaginatively in the reader's mind (elaboration).

This initial blend, however, is only the beginning. After a reader develops their initial character model, "[that mental model] is continually updated to incorporate the latest information, as with all mental representations in text comprehension. ${ }^{29}$ While the processes involved in updating the initial blended space are largely the same as in the creation of the initial blended space, I suggest we alter the basic model above in Figure 3 to depict the initial appearance (the original blended space) as an input space and the subsequent appearance

26 Similarly, Fauconnier and Turner, The Way We Think, p. 253; Schneider, "Blending," p. 17.

27 Schneider, "Blending," p. 17. I do not claim that personalization has no role in the blend between a character and a frame; my point is that the process is categorization dominant. Schneider implies that this type of blending is the means by which dynamic mental modeling of characters occurs. One benefit of this type of blend over traditional dynamic processing one is that it accommodates and represents piecemeal integration of multiple character types to inform a reader's initial characterization (via cross-space mapping). On the mental modeling of characters, see Schneider, "Toward a Cognitive Theory," pp. 607-640 (627). Together with Schneider, I think of "frames" as one type of mental space, which can be activated within a Blend either as a frame or as an input space, depending on the context.

28 So also, Schneider, "Blending," p. 17. This type of blend likely uses the same mental processes as blends between characters and frames.

29 Schneider, "Toward a Cognitive Theory," p. 617. Cf. A. Collins, J.S. Brown and K.M. Larkin, "Inference in Text Understanding," in Theoretical Issues in Reading Comprehension (London: Routledge, 2017), p. 387; A.M. Glenberg, M. Meyer and K. Lindem, "Mental Models Contribute to Foregrounding During Text Comprehension," J Mem Lang 26 (1987), pp. 69-83; R.A. Zwaan and G.A. Radvansky, "Situation Models in Language Comprehension and Memory," Psychol Bull 123 (1998), p. 162. 


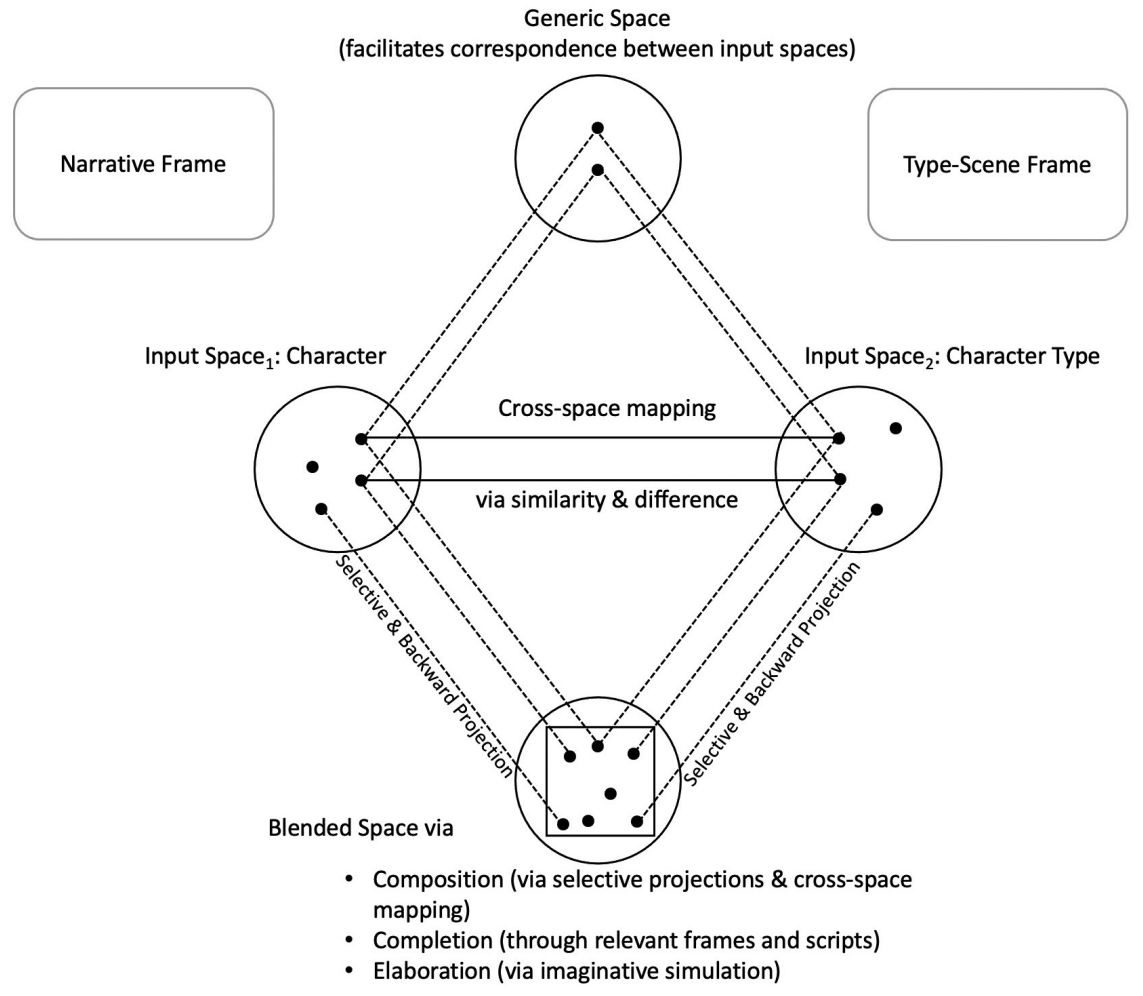

FIGURE 3 Blending a Character \& Character Type(s)

as an additional input space. Resonance and dissonance via cross-space mapping will ultimately facilitate confirmatory categorization, decategorization/ individuation, and/or recategorization in the completion and elaboration steps (see Figure 4 below). ${ }^{30}$

The initial blended mental model of the character, including the setting, their actions, purpose, reply (and/or interlocutor's response), and the consequences of those (inter)actions become one input space and those of their next appearance in the narrative become the other input space. As with any other blend, selective projection based on similarities and differences between the initial and subsequent appearances via cross-space mapping populates the blended space (composition). Depending on which frames the blending space activates during completion, readers might experience confirmatory categorization, individuation, decategorization, or recategorization of their rendering of

30 For an alternative arrangement of frames in relation to the input spaces, see Hartvigsen, pp. $71^{-} 75$. 


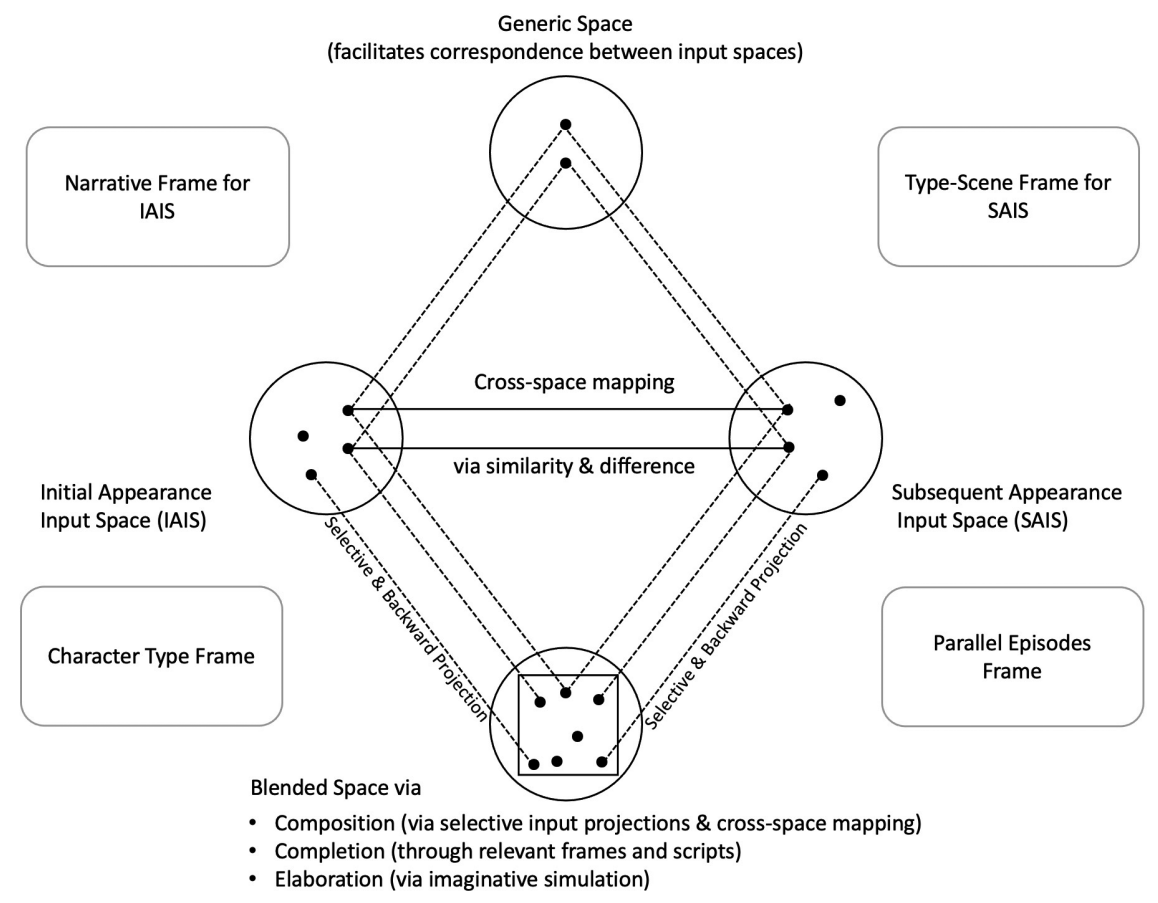

FIgURE 4 Blend Model for Subsequent Character Appearances

the initial characterization vis-à-vis the subsequent appearance. This process repeats for each subsequent appearance, with the new blended space always becoming the next input space with which the next appearance blends. To illustrate the utility of this two-step recursive model, I now revisit the characterization of Nicodemus in John's gospel. ${ }^{31}$

\section{Blending Nicodemus ${ }^{32}$}

In what follows, I represent the mental processes we might expect from ancient readers constructing Nicodemus in John's gospel and discuss their outcomes. I begin by representing Nicodemus's initial appearance in John 3 as a blend of character and character types.

$31 \quad$ By "recursive" I mean that the second of the two steps (blending subsequent appearances) happens each time the character makes an appearance in the narrative.

32 Since space does not permit a rehashing of all the viable frames potentially involved in the dynamic process of Nicodemus's characterization, see Whitenton, Configuring Nicodemus, pp. 55-106. 


\section{Initially Constructing Nicodemus in John 3:1-21 (=Nic A)}

I have written on multiple occasions why I believe ancient audiences would likely categorize Nicodemus in John's gospel, at least initially, as a Pharisaic dissembler who loves the darkness instead of God's logos (cf. John 3:20). ${ }^{33}$ The blend in Figure 5 below represents Nic A as a blend between textual artifacts in the interaction between Nicodemus and Jesus in John 3:1-21 and character types activated within the text (PHARISEE) and external to the text (DISSEMBLER).

According to the model above, the blend begins as their minds encounter the text of John 3:1-21, Nicodemus's interaction with Jesus would activate the character types for PHARISEE and DISSEMBLER.

(1) Composition: For attentive ancient readers, Nicodemus's exchange with Jesus will probably activate the PHARISEE and DISSEMBLER character types as mental spaces. I have treated these character types as input spaces to illustrate the dynamic mental modeling that occurs because of selection, connection, and comparison (resonance and dissonance) through cross-space mapping. These correlating elements will initially populate the blended space through selective projection.

Figure 5 above indicates the ways Nicodemus's identification as a "Pharisee" (and a Jewish leader) would encourage readers to map their expectations about Pharisees onto Nicodemus. Yet Nicodemus's behavior-particularly his combination of praise for Jesus and his apparent misunderstanding of relatively simple concepts-would also encourage selective cross-space mapping between Nicodemus and expectations surrounding the DISSEMBLER character type. The integration of these three mental spaces (Nicodemus, PHARISEE, and DISSEMBLER) is much clearer in a blending model than a traditional dynamic processing model.

During the composition of the blended space, backward projection to the three input spaces ("Nicodemus" in John 3, the PHARISEE character type, and the DISSEMBLER character type), introduces new structures to audience perceptions of them. In other words, backward projection changes the content of the PHARISEE and DISSEMBLER character types because they participated in the blended space. For example, a PHARISEE mental space may now include some level of dissembling, self-deprecation, hunger for power, etc. Similarly, within John's gospel, a dissembler's duplicitous character would seem to oppose God's true logos. 


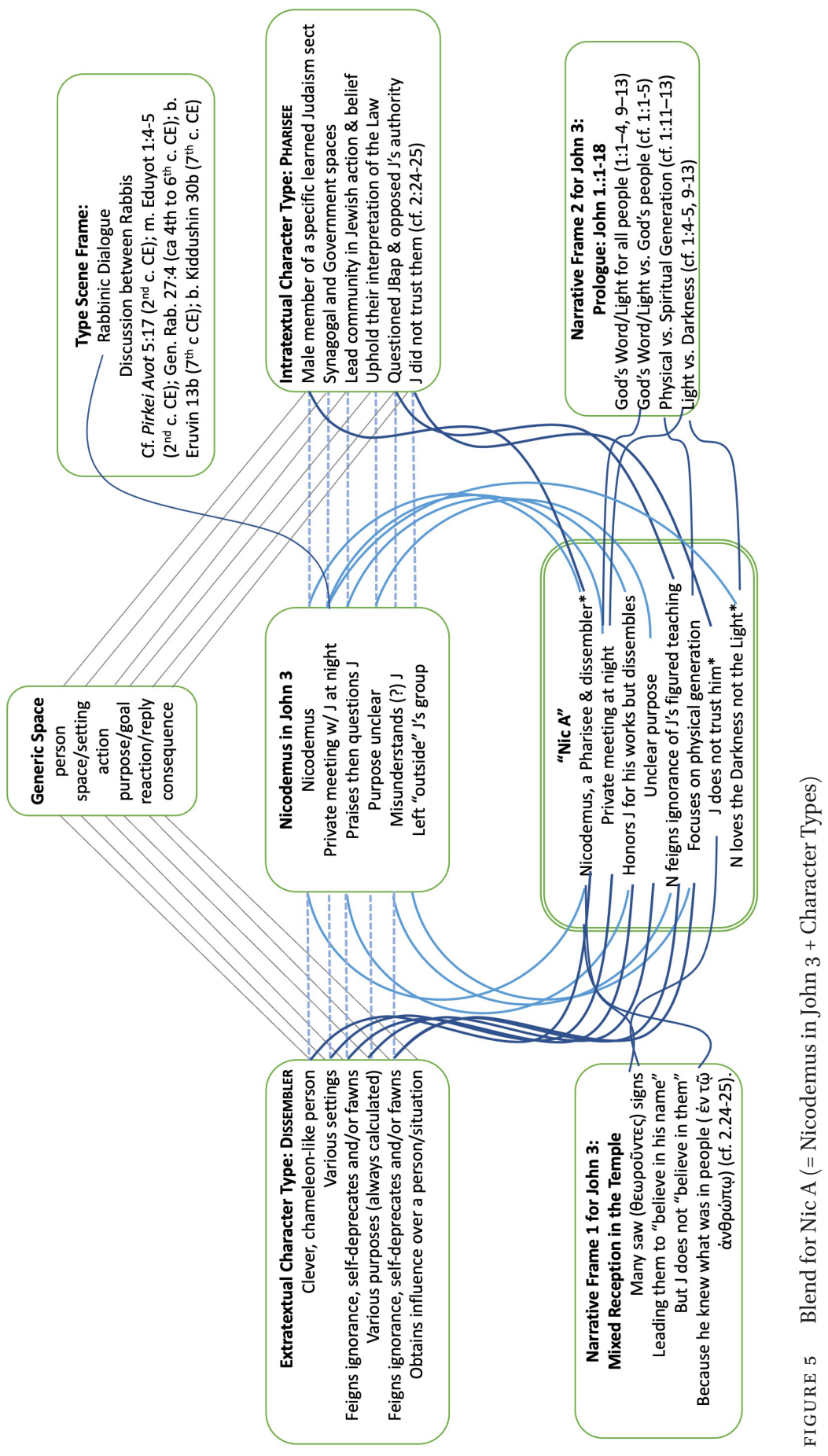


(2) Completion:To bring structure to the blend, readers will need to draw upon information that falls outside the input spaces. Inferences at this level help "complete" the initial composition via categorization. According to Figure 5 , at least three such "frames" play a role in completing the blend of Nic A: (1) the Rabbinic dialogue type scene; (2) Jesus's mixed reception in the Temple (John 2:13-25); and (3) the Prologue (1:1-18).

(a) The RABbinic Dialogue Type Scene: Rabbis (and sometimes their disciples) would often debate questions about interpreting the Law or some related aspect to Jewish practice and belief. ${ }^{34}$ Sometimes these debates happened in the evening, but they need not only occur after dark. ${ }^{35}$ Furthermore, exchanges between two rabbis on the nature of spiritual transformation (cf. 3.1-10) would presumably activate audience associations with such a common practice.

(b) Jesus's mixed reception in the temple (2:13-25) narrative frame: Jesus made a whip and chased the moneychangers out of the temple, offering the resurrection of body-as-temple as a sign of his authority to do so. Similar to Nicodemus in John 3, "the Jews" take Jesus's figured statement: "Destroy this temple, and in three days I will raise it up" literally and are thus incredulous (2:19-20). Even his disciples only recognize the metaphorical truth of his teaching after his resurrection (2:22). Nevertheless, "many believed in his name" ( $\dot{\pi} \pi i \sigma \tau \varepsilon v \sigma \alpha \nu)$ because of the signs (2:23). Yet Jesus would not

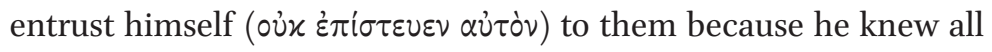

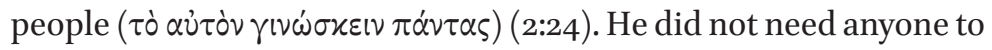

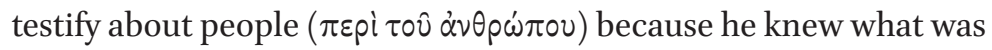

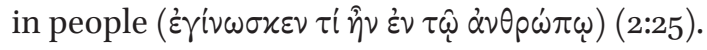

The repetition of $\alpha \nu \theta \rho \omega \pi \circ \varsigma$ in 2:24-25 primes audiences to organize their construction of Nicodemus, as one such $\ddot{\alpha} \nu \theta \omega \omega \pi$ ( $3: 1)$, in a suspicious light. The reason for this suspicion is that Jesus's knowledge of such $\ddot{\alpha} \nu \rho \omega \pi$ ol suggests a hostile incongruity between their claims to believe and their actual orientation to God's logos. This division between such $\ddot{\alpha} \nu \theta p \omega \pi 0 \mathrm{r}$ and Jesus is especially compelling

34 Cf. Pirkei Avot 5:17 (second century CE); m. Eduyot 1:4-5 (second century CE); Gen. Rab. 27:4 (ca fourth to sixth century CE); b. Eruvin 13b (seventh century CE); b. Kiddushin $30 \mathrm{ob}$ (seventh century CE). These dialogues do resemble Greek philosophical debates to some degree.

35 So also, C.S. Keener, The Gospel of John: A Commentary (Peabody, MA: Hendrickson, 2003), p. 536 . 
considering the thematic overlap with the final narrative frame in the blend: the Prologue (1:1-18).

(c) The Prologue (1:1-18) narrative frame: The Prologue of John's gospel $(1: 1-18)$ provides an interpretive grid through which readers ought to understand the rest of the gospel..$^{36}$ According to Aristotle, prologues ought always to provide a guide for readers (Rhet. 3.14.1). ${ }^{37}$ Similarly, cognitive scientists, literary critics, and communication scholars have all noted the "primacy effect," in which the beginning of a narrative becomes its interpretive lens. ${ }^{38}$ Unsurprisingly, then, Nicodemus's exchange with Jesus in John 3 organically maps onto the Prologue. God's logos created everything that has come into being (1:3), including life itself. The Prologue casts this life metaphorically as a struggle between light and darkness (1:4), which tried, unsuccessfully, to overcome ( $\chi \alpha \tau \varepsilon \dot{\lambda} \alpha \beta \varepsilon v)$ the light of God's logos (1:5). The conflict is especially apparent between God's logos and "the Jews":

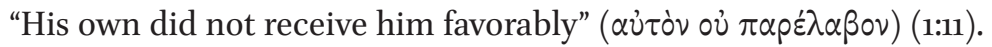
But God's logos conferred the power to be "born" as children of God to those who did receive him favorably $(1: 12-13) \cdot{ }^{39}$ As with creation

36 Such a claim is by no means contentious, going back in modern scholarship at least as early as W. Baldensperger, Der Prolog des vierten Evangeliums, sein polemisch-apologetischer Zweck (Tübingen: Mohr, 1898); A. Loisy, Le Quatrième Evangile (Paris: Picard, 3rd edn, 1903). More recently, see, e.g., M. Theobald, Die Fleischwerdung des Logos: Studien zum Verhältnis des Johannesprologs zum Corpus des Evangeliums und zu IJoh (NTAbh, 20; Münster: Aschendorff, 1988); C.W. Skinner, "Misunderstanding, Christology, and Johannine Characterization: Reading John's Characters through the Lens of the Prologue," in C.W. Skinner (ed.), Characters and Characterization in the Gospel of John (LNTS, 461; London: T\&T Clark, 2013); J.-A.A. Brant, John (Paideia, Grand Rapids: Baker Academic, 2011), p. 23; Keener, pp. 333-339.

37 See also, Cicero, De or. 2.315; Quintilian, Inst. 4.1.5; Theon Prog. 34, Lucian, How to Write History 53. Cf. Virgil, Aen. 1.1-6; Josephus, J.W. 1.17-30; Polybius 3.1.3-3.5.9, esp. 3.1.7; 11.1.1-2; Aulus Gellius, pref. 25 as noted in Keener, p. 334n310. So too, H.-J. Klauck, "Hellenistische Rhetorik im Diasporajudentum Das Exordium des Vierten Makkabäerbuchs (4 Makk 1.112)," NTS 35 (1989), pp. 451-465. See further, Whitenton, Configuring Nicodemus, pp. 81-85. Cf. Whitenton, Hearing Kyriotic Sonship, pp. 98-108.

38 See, e.g., P. Stockwell, Cognitive Poetics: An Introduction (London: Routledge, 2002); C.A. Castro, "Primacy and Recency Effects," in W.E. Craighead and C.B. Nemeroff eds., The Corsini Encyclopedia of Psychology and Behavioral Science (New York: Wiley, 20o1), vol. 3. Malbon also recognized this phenomenon in her "Ending at the Beginning: A Response," Semeia 52 (1990), pp. 175-184 (178-181).

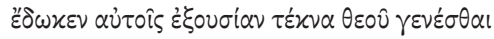


itself, and in contrast to literal human conception and birth, God's logos confers divine birth through speech and stands (1:13). ${ }^{40}$

As the minds of the readers run the completion step, the relevant elements of the Rabbinic dialogue type scene, the Prologue (1:1-18), and Jesus's mixed reception in the temple (2:13-25) structure the blended space in ways that organize and create new relationships between selected elements of Nicodemus's interaction with Jesus, the PHARISEE character type, and the DISSEMBLER character type. This step in the blend yields emergent material that exists only in the blend: In their initial encounter with Nicodemus, ancient audience members will likely categorize him as a dissembling Pharisee via completion.

(3) Elaboration: Once readers have created the blending space (NicA) (composition) and structured it according to relevant frames that introduce emergent meaning found only in the blend (completion), the minds of readers will imaginatively simulate Nicodemus's interaction with Jesus (Nic A is a dissembling Pharisee), according to the internal logic of John's gospel (elaboration). Here, elaboration will entail projecting what it means that Nicodemus is a dissembling Pharisee who has yet to "come to the Light" when his interaction with Jesus ends.

Blending helps show how a dynamic processing theory of character works to assimilate a character into a frame (or a mashup of various frames). Perhaps most importantly, it accounts for emergent structures in the blended space (e.g., Nic A is a Pharisaic dissembler \& loves the darkness rather than the light) via processes largely either assumed or ignored by typical dynamic processing models (including my previous work). Just as a character integrates with a character type, blending also shows how subsequent appearances of a character integrate into the earlier appearances in the same narrative.

If readers/hearers construct Nic A as a Pharisaic dissembler who loves the darkness instead of the light of God's logos, integrating Nicodemus's second appearance (John 7:45-52) via blending complicates matters considerably.

\section{Integrating Nicodemus's Subsequent Appearances in John}

In Configuring Nicodemus, I argued that Nicodemus's appearances in John 7 and 19 individuated or nuanced his characterization in John 3 in ways that suggest, by the story's end, Jesus's rhetoric in 3:1-21 eventually transforms him into a

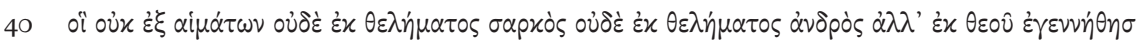
$\alpha v$. On divine birth in John's gospel, see A.D. Myers, Blessed Among Women?: Mothers and Motherhood in the New Testament (New York: Oxford University Press, 1st edn, 2017). 
spiritually "born" child of God (cf. 1:11-13). ${ }^{41}$ However, because dynamic processing models alone do not adequately represent such individuation/personalization, below I offer blending models integrating Nicodemus's subsequent appearances, starting with the blend of the material in John 7:45-52 with Nic A.

\section{Constructing the Blend for Nic B (= John 7:45-52 x Nic A)}

Blending multiple character appearances works from the same basic framework as blending a character and character types. However, in Figure 6 below, I have represented the character types as frames in the blend. This arrangement allows me to represent cross-space mapping between-and selective projection from-Nicodemus's appearances with greater precision. It also more clearly shows how the respective frames contribute to the completion of the blended space. Ultimately, the integration of John 7:45-52 and Nic A reaffirms some initial categorizations while encouraging personalization in other aspects of Nicodemus's character.

\section{Integrating Nicodemus's Second Appearance (John 7:45-52) with His First (Nic A)}

According to the blend above in Figure 6, as the minds of readers/hearers encounter the text of John 7:45-52, they will integrate Nicodemus new behavior and actions into their mental model of "Nicodemus in John's gospel" (which until now has been synonymous with Nic A). This integration will create a blended space (composition), bolstered by relevant frames and prior knowledge (completion). At this point, readers will run an imaginative simulation of the scene consistent with the narrative's internal logic (elaboration). "Running the blend" in this manner will yield a more nuanced characterization of Nicodemus (=Nic B) when compared to Nic A. As before, Nicodemus's interaction with the Pharisees would activate the character types for PHARISEE and DISSEMBLER, the SINGLE VOICE OF REASON type scene frame, and the Prologue as a narrative frame (John 1:1-18).

(1) Composition For attentive ancient readers familiar with his first appearance, Nicodemus's exchange with the Pharisees would readily map onto their mental space for a Nic A. Repeated expressions that direct audience attention to a particular episode—or what Barbara Dancygier calls

41 See Whitenton, Configuring Nicodemus, pp. 107-118. 


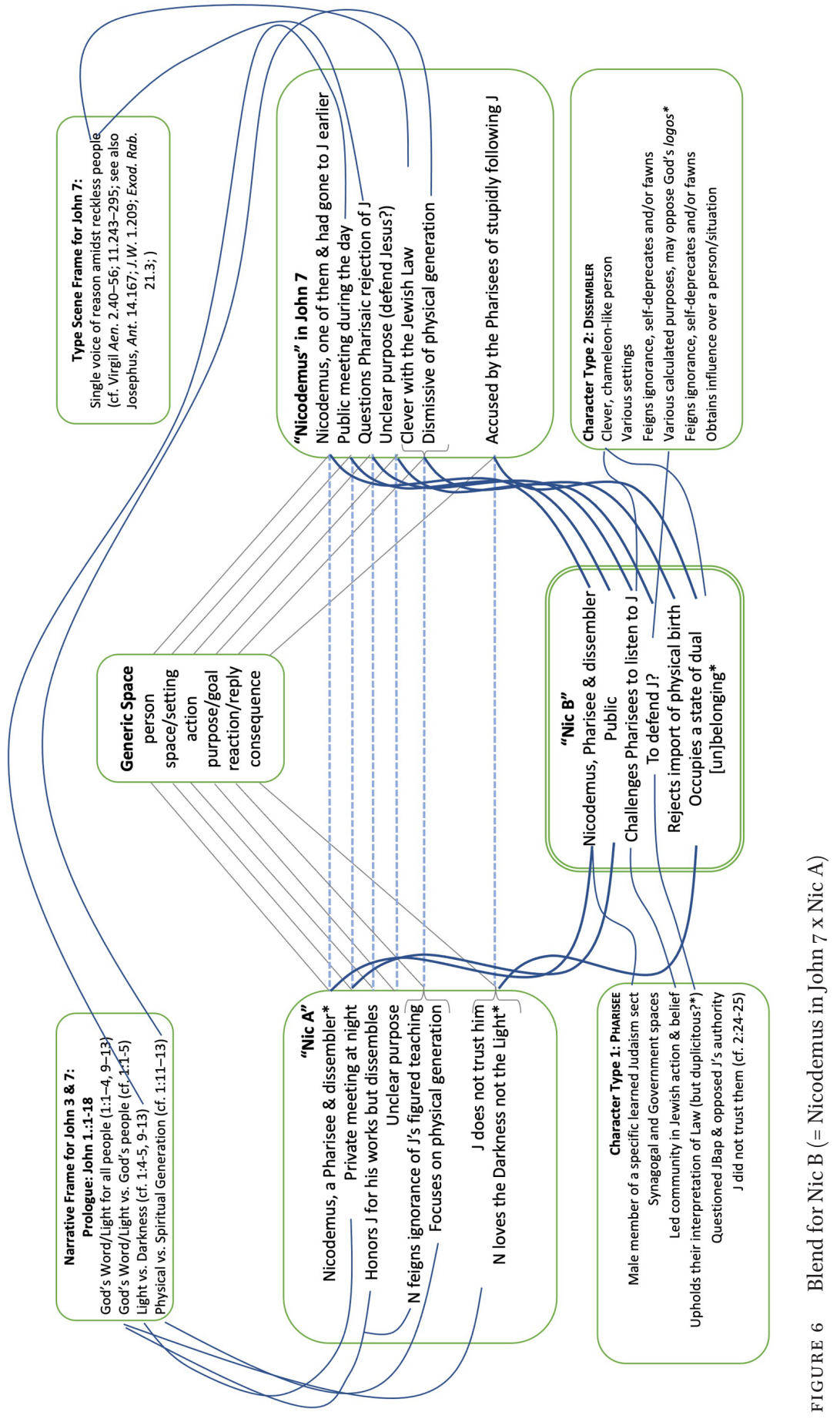


"narrative anchors"—galvanize such mapping. ${ }^{42}$ These enthymematic phrases activate, for attentive readers/hearers, an entire mental space without the need to rehearse all the essential details. That critical task belongs to the reader and enhances audience participation. ${ }^{43}$ This retrieval of narrative anchors facilitates cross-space mapping by compressing space and time to construct the "story." In John 7:50, the narrator's description of Nicodemus as "one of [the Pharisees]" who "had come to Jesus earlier," cues the narrative anchor (Nicodemus's encounter with Jesus) and compresses it with immediate narrative space (7:45-52) in terms of space and time. This compression highlights the resonance and dissonance between the two appearances.

The input spaces resonate to some degree, but dissonance does the heavy lifting in the integration of John 7:45-52 with Nic A. During compression, selective cross-space mapping confirms the categorizations of Nicodemus as PHARISEE and DISSEMBLER (see Figure 5 above). However, the changing contexts (private vs. public) and narrative audiences (Jesus vs. other Pharisees) personalize both categorizations. ${ }^{44}$ Depending on the significance hearers assign to darkness/ night and light/daytime, the dissonance between private and public settings may produce emergent material in the blended space (see below on "completion"). ${ }^{45}$ Nicodemus came to Jesus privately at night in John 3, but, in John 7 ,

42 B. Dancygier, "Narrative Anchors and the Processes of Story Construction: The Case of Margaret Atwood's The Blind Assassin," Style 41 (2007), pp. 133-151; B. Dancygier, "The Text and the Story: Levels of Blending in Fictional Narratives," in T. Oakley and A. Hougaard (eds.), Mental Spaces in Discourse and Interaction (Amsterdam: Benjamins, 2008).

43 On which, see Whitenton, Configuring Nicodemus, pp. 96-101.

44 The continued recruitment of the dissembler frame (via narrative anchoring) also reinforces audience uncertainty and (hopefully) curiosity about Nicodemus's motivations. Like his dissembling predecessors, Nicodemus's beheavor is intentionally ambiguous or, perhaps better, polysemous. On value of polysemy in ancient rhetoric vis-à-vis ancient dissemblers, see Whitenton, Configuring Nicodemus, pp. 96-103. On polysemy, see further C.M. Condit, "The Rhetorical Limits of Polysemy," Crit Stud Media Commun 6 (1989), pp. 103-122; L. Ceccarelli, "Polysemy: Multiple Meanings in Rhetorical Criticism," Qjs 84 (1998), pp. 395-415; R.F. Thomas, "A Trope by Any Other Name: "Polysemy," Ambiguity, and Significatio in Virgil," HSCP 100 (2000), pp. 381-407. Cf. F. Ahl, "The Art of Safe Criticism in Greece and Rome," AJP 105 (1984), pp. 174-208.

45 Scholars have long debated the significance of the timing of Nicodemus's visit, typically raising two basic possibilities: (1) Jewish teachers often studied during the evening, especially if they worked during the day (see, e.g., 1Q s 6.6-7; t. Šabb. 1:13; b. 'Abod. Zar. 3b). On which, see F.P. Cotterell, "The Nicodemus Conversation: A Fresh Appraisal," ExpTim 96 (1985), pp. 237-242 (238); R. Bauckham, "Nicodemus and the Gurion Family," JTS 47 (1996), pp. 1-37 (31); M.M. Beirne, Women and Men in the Fourth Gospel: A Genuine Discipleship of Equals (JSNTSup, 242; London: Sheffield Academic Press, 2003), p. 73. (2) Nicodemus wishes to avoid being seen (cf. John 7:51-52; 12:42-43; 19:38; Judg 6:27; 1 Sam 28:8; 2 Kings 25:4; 
he confronts the Pharisees publicly during the day. The nature of Nicodemus's questions has also changed from a reactionary self-deprecation ("How can this be?!" [3:9]) to a calculated injunction to obey to the Law by listening to Jesus (the interrogative mood provides plausible deniability) $\left(7: 45^{-52}\right){ }^{46}$ In the latter, Nicodemus's question forces the Pharisees to choose between their interpretation of the Prophets and their reputation as accurate interpreters of the Law. ${ }^{47}$ Their opposition to Jesus forces them to abandon the Law and mock Nicodemus as a "Galilean." As for the shifting audience, Jesus cannot contain his amazement with the level of (ostensible) ignorance in Nicodemus's questions $(3: 7,10)$, while the Pharisees mock him, suggesting (ironically, correctly) that he must now believe in Jesus (7:47-49). For some readers, the differences between the first and second appearances may personalize Nicodemus's dissembling and his status as a Pharisee in ways that suggest service to Jesus.

Dissonance in the cross-space mapping between Nicodemus's focus on physical generation in John 3 and his lack of concern for the physical generation of the messiah in John 7 may further individuate Nic B from Nic A, suggesting an openness to, or perhaps a deepening understanding of, Jesus's message of spiritual birth (birth $\ddot{\alpha} v \omega \theta \varepsilon v)$. In John 3, Nicodemus almost comically fixates on physical conception and vaginal birth. ${ }^{48}$ However, by the time readers reach 7:45-52, Nicodemus shows no interest in the messiah's physical birth(place). Instead, he pushes his colleagues (unsuccessfully) to overlook such debates involving physical origins and encounter Jesus as he did. This shift presumably would lead some readers to conclude that Nicodemus occupies a sort of liminal space of dual (un)belonging. He no longer sees eye to eye with his Pharisaic colleagues regarding how to respond to Jesus, and while he seems to defend

Sophocles Ajax 47). Those who opt for option \#2 usually understand Nicodemus as some sort of secret disciple. On which, see C. Bennema, Encountering Jesus: Character Studies in the Gospel of John (Milton Keynes, UK: Paternoster, 20o9), pp. 150-151; J. Painter, The Quest for the Messiah: The History, Literature and Theology of the Johannine Community (Edinburgh: T\&T Clark, 1991); C.R. Koester, Symbolism in the Fourth Gospel: Meaning, Mystery, Community (Minneapolis: Fortress, 1995), p. 45; H. Ridderbos, The Gospel of John: A Theological Commentary (Grand Rapids: Eerdmans, 1997), p. 123; F.J. Moloney, The Gospel of John (sP, 4; Collegeville, MN: Liturgical Press, Revised edition edn., 2005), p. 510. See also Keener, p. 536; R.E. Brown, The Gospel According to John I-XII (AB, 29; Garden City: Anchor Bible, 1966), p. 130.

46 On plausible deniability as a common motivation behind dissembling, see Quintilian, Inst. 9.2.68.

47 Nicodemus's insistence that the Law demands they give Jesus a hearing follows conventional precedent (see Josephus, Ant. 14.167; J.W. 1.209; Exod. Rab. 21.3). Cf. Brant, p. 141.

48 On the potential for humor in John 3 - and its rhetorical effect - see Whitenton, Configuring Nicodemus, pp. 120-136. 
Jesus via the Law, neither does he unequivocally identify as a Jesus follower. However, the narrative hints at Nicodemus's belief by reintroducing him in the narrative immediately after the Pharisees castigate the guards, who have just come from listening to Jesus's figured living water speech (cf. John 4:13-15). When the guards respond that they did not capture him because of his rhetorical prowess ("No one has ever spoken like that."), the Pharisees scoff, saying, "You haven't been deceived too, have you? Nobody from among the leaders has believed in [Jesus], have they? Have any of the Pharisees? But this crowd, which does not know the law - they are accursed" (7:48-49). ${ }^{49}$ The next person to speak is none other than Nicodemus. The scene drips with irony for those who infer that Nicodemus is a Pharisee who believes in Jesus. Put another way, cross-space mapping between the input spaces encourages ancient audiences to individuate Nic B from Nic A in terms of a change of allegiance, or better, as a change in loves. While Nic A loved the darkness instead of the light in John 3, Nicodemus's daytime defense of Jesus suggests that Nic B now loves God's light.

To make sense of all this, audience members will need to recruit relevant frames to better structure and organize the blended space.

(2) Completion As with Figure 4 above, the lines connecting the narrative, type scene, and character types to the input spaces and the blended space in Figure 5 indicate their influence in organizing and filling out the blended space. ${ }^{50}$

(a) Narrative Frame (Prologue): The Prologue's focus on the conflict between God's logos and his own people, couched in a metaphorical battle between light and darkness, continues to provide an instructive framework. Importantly, Nicodemus's positioning within these themes seems to have shifted. While God's logos remains in conflict with the Jewish leadership, Nicodemus (literally and metaphorically) steps into the light to challenge their rejection of Jesus (cf. 1:4-5, 10-13). In terms of framing, the Prologue primes readers to interpret "night" as aligning Nicodemus with the "darkness" in 3:2 (cf. 13:30), whereas his public and frank defense of Jesus takes place (presumably) during the day. ${ }^{51}$

49 Attentive audience members might make the inference that Jesus's divine speech has swayed Nicodemus, just as it had the Samaritan woman (cf. 4:4-42).

50 Note that backward projection onto the Pharisee and Dissembler frames (which previously acted as input spaces) reflects emergent material from their role in the blend for Nic A.

$5^{1}$ On frankness of speech ( $\left.\pi \alpha p p \eta \sigma i \alpha\right)$ in ancient rhetoric, see Lib., P.Herc. 1471, col. 8b.6-13, quoted in Brant, p. 141. See also, D. Konstan, Friendship in the Classical World (ктAн, 6; Cambridge: Cambridge University Press, 1997), p. 21. 
(b) Type Scene Frame(s): SINGLE voice of REASON: In these type scenes, which were common in contemporary literature, a single individual arrives in the scene to stop a group of people from making a disastrous decision. Ironically, the crowds typically ignore that voice of reason (e.g., Virgil Aen. $2.40-56$; 11.243-295). ${ }^{52}$ Those for whom the SINGLE VOICE OF REASON type scene is activated would easily assimilate Nicodemus as that voice, putting further distance between him and his Pharisaic colleagues.

(c) Character Type 1 (PHARISEE): As the voice of reason, attempting to lead the Jewish community right action, Nicodemus's failed intervention by appealing to the Law (re)activates the PHARISEE frame during the completion step. Recall from Figure 4 above that the PHARISEE frame gained emergent structure via backward processing with Nic A ("duplicity"). Activating the (duplicitous) PHARISEE character type at this point in the narrative via selective projection reinforces the idea that Nicodemus is attempting to defend Jesus in 7:45-52.

(d) Character Type 2 (Dissem bleR): The Dissemblen character type also gained emergent structure because of the construction of Nic A (in Figure 4, I noted opposition to God's logos as a potential motivator for a DISSEM BLER ). Ironically, if Nicodemus's behavior in John 7:45-52 (re)activates the DISSEMBLER character type, it will be in the context of defending God's logos, not opposing it. Nicodemus's suggestion that they offer Jesus a hearing may strike audience members as a carefully calculated strategy. The Pharisees cannot believe that Nicodemus is defending Jesus. The interrogative provides him with plausible deniability. Instead, he asks a question, which ancient rhetoricians widely recognized as more persuasive for non-sympathetic crowds than direct statements. ${ }^{53}$ While he does not feign ignorance, his interrogative tone may give the impression of naivety. Ancient audience members who remember Jesus's own clever rhetoric toward Nicodemus might realize that Nicodemus, too, has adopted emphasis as a dissembling technique. ${ }^{54}$ Because his rhetoric now reflects the rhetoric of God's logos, the Pharisees' rejection of Nicodemus is tantamount to a rejection of Jesus.

$52 \quad$ See also Keener, p. 733 .

53 See, e.g., Ps-Demetrius, Eloc. 279; Ps-Longinus, [Subl.] 18.1-2; Rhet. Her. 4.15.22; Quintilian, Inst. 9.2.7-11.

Cf. Rhet. Her. 4.53.67; Quintilian, Inst. 9.2.67-74; Ps-Demetrius, Eloc. 222 
Nevertheless, the clever, even chameleon-like, quality of the DISSEMBLER, if projected onto Nicodemus, would reinforce uncertainty regarding his standing in John's gospel. While Nicodemus's behavior in John 7:45-52 will probably lead many readers to categorize him as either a Pharisee or a (Pharisaic) Jesus follower, those for whom the DISSEMBLER frame is strongly activated may withhold judgment. Dissemblers were notoriously untrustworthy. 55

In sum, the completion step recruited frames that ultimately confirmed audience categorizations of Nic B as a dissembler and Pharisee, but other frames (SINGLE VOICE OF REASON) and narrative context (7:45-49) personalize his dissembling and Pharisaic identity in a way that suggests a change in loves.

(3) Elaboration The recursive nature of characterization-as-blending suggests a great deal of dissonance occasioned by the backward projection of Nic B (lover of Jesus) onto Nic A (lover of darkness), which readers will need to resolve. More traditional literary approaches sometimes suggest that readers ought to allow the characterization of Nicodemus to hover between these two representations. The result is that Nicodemus is "ambiguous," perhaps even intentionally so. ${ }^{56}$ While my comments above show that I do not deny this possibility at this point in the narrative, as I have argued elsewhere, the human mind prefers stability to instability and coherence over tension. ${ }^{57}$ Instead of living in the tension between two poles, as Schneider puts it, "we can expect the mind to create meaning out of opposed items and seemingly incompatible inputs" for character identity in literary narratives. ${ }^{58}$

While it is too early for final judgments, it would seem that Nic B has changed the object of his love, leading to the audience inference that Jesus's clever rhetoric in John 3 may well have given Nicodemus a spiritual transformation. ${ }^{59}$

55 A later note appended to the description of the dissembler in Theophrastus reads, "One should be more wary of disingenuous and designing characters than of vipers." See J. Diggle ed., Theophrastus: Characters (trans. J. Diggle; CCTC, 41; Cambridge University Press, 2004), p. 167 .

56 See, e.g., J.M. Bassler, "Mixed Signals: Nicodemus in the Fourth Gospel," JBL 108 (1989), pp. 635-646; S.E. Hylen, Imperfect Believers: Ambiguous Characters in the Gospel of John (Louisville: Westminster John Knox, 2009), pp. 23-40.

57 Whitenton, Configuring Nicodemus, pp. 79-8o (esp. 8o n. 78.

58 Schneider, "Blending," p. 15.

59 By contrast, Nicodemus's defense of Jesus in John 7 will confirm his insider status for those who constructed Nic A as a (secret) Jesus follower. 


\section{Constructing the Blend of Nic C (= John 19:38-42 x Nic B)}

In John 19, Nicodemus's actions, combined with narrative framing, now far exceed those of Nic B in ways that lead attentive audiences to recategorize Nicodemus as Jesus's disciple and peerless bereaved companion. Figure 7 below represents the formation of Nic C via the integration of Nicodemus's appearance in John 19 with Nic B. While many interpreters have sterilized Nicodemus's extravagant actions, reducing them to underscoring "the orderly, even exceedingly dignified burial given to Jesus," the blend below suggests a more impassioned undertaking. ${ }^{60}$

\section{Integrating "Nicodemus (John 19)" with Nic B}

According to Figure 7 above, as the minds of readers/hearers encounter the text of John 19:38-42, they will integrate relevant material into their mental model of "Nicodemus in John's gospel" (which has shifted from "Nic A" to "Nic B"). In particular, cross-space mapping and selective projections from Nic B and "Nicodemus in John 19" begin populating the blended space in ways (composition) that will individuate Nicodemus away from the DISSEMbler categorization and confirm the recategorization of Nicodemus as a JOHANNINE DISCIPLE and BEREAVED COMPANION (completion). Ancient audience members will imaginatively simulate this new emergent structure according to the internal logic of John's gospel (elaboration). Ultimately, I argue that Nicodemus emerges as the Johannine disciple who loves Jesus the most.

(1) Composition: For attentive ancient readers familiar with his journey to this point, Nicodemus's participation in the retrieval and burial of Jesus's body in John 19:28-37 would readily interact with their mental space for Nic B via resonant cross-space mapping. In both mental spaces, Nicodemus acts on Jesus's behalf publicly. Nic B publicly challenged his colleagues to give Jesus a hearing, even if he does not respond to their mockery. ${ }^{61}$ However, his public retrieval of Jesus's body and his extravagant gift of myrrh and aloes goes far beyond Nic B's legal question in John 7:45-52. Some in the audience may understandably wonder whether any

6o It is true that no emotion is attributed to Nicodemus, but that does not preclude ancient audiences projecting appropriate emotions onto Nicodemus in the blend. In fact, that is exactly what we would expect them to do. On audience emotion in response to narrative, see Keen, pp. 6-100; Whitenton, "Feeling the Silence," pp. 272-289.

61 Motivation for that silence is not explicitly stated, but those who understand Nic B as a dissembler may infer that he is hedging. 


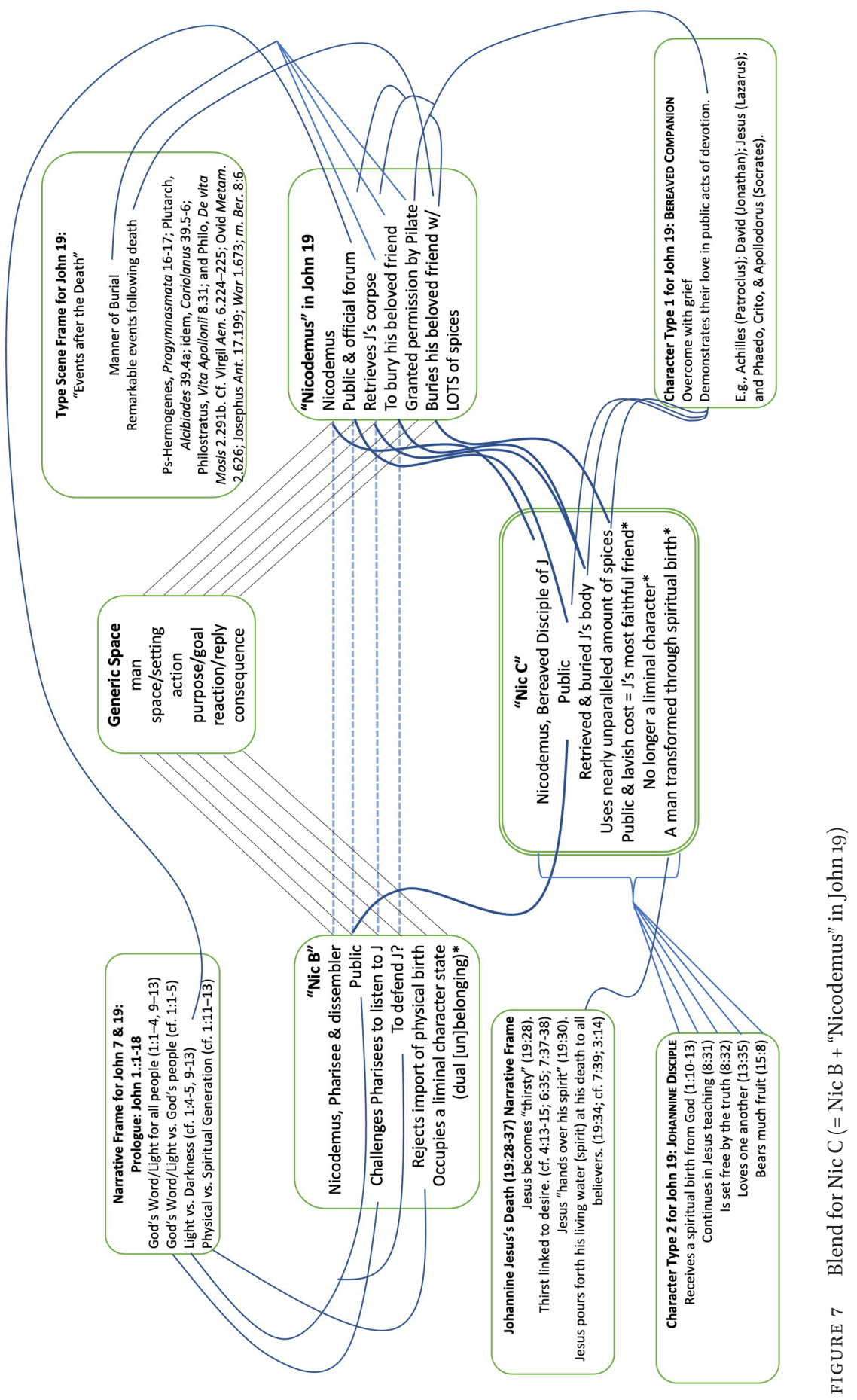


character in the story has shown affection for God's logos greater than this bereaved friend of Jesus. For such audience members, these actions and their setting would probably cue several relevant frames in completion that prompt either confirm the categorization of Nicodemus (or recategorize him) as a JOHANNINE DISCIPLE.

(2) Completion: The narrative frames below organize and structure the blended space populated by composition.

(a) Johannine Jesus's Death (19:28-37) Narrative Frame: The JOHANNINE JESUS'S DEATH frame provides a ready scaffolding for structuring Nic $\mathrm{C}$ as a man transformed by the spirit Jesus promised to send after his "glorification" (cf. 7:39) 62 $^{\text {Joseph and Nicodemus }}$ retrieve Jesus's body immediately after the audience learns of his death (19:28-37). Attentive audience members will probably attribute symbolic meaning to the blood and water that burst from Jesus's pierced chest in keeping with his speech at the Festival of Sukkot: "Let anyone who is thirsty come to me, and let the one who believes in me drink. As the scriptures have said, 'Out of the believer's heart shall flow rivers of living water" (John 7:37-38). ${ }^{63}$ This living water was none other than the spirit, which Jesus would give after he was "glorified" (7:39; cf. 3:14). Now that Jesus's glorification-as-crucifixion has come, he has delivered on his promise of the spirit. As readers organized their mental model of $\mathrm{Nic} \mathrm{C}$, a reasonable inference would be that Nicodemus has now been "born from above" via Jesus's promised spirit, symbolized by blood and water pouring forth from his side (cf. 19:34).

(b) PRologue (1:1-18) Narrative Frame: Jesus's death-as-glorification forms the crescendo of the conflict between the darkness and God's ever-shining light (cf. 1:3-5). The darkness has tried and failed to overcome God's light (cf.:1:5). This episode,

62 "Glorification" ( $\dot{\delta} \delta \xi_{\dot{\alpha}} \sigma \theta \eta$ in 7:38) almost certainly refers metaphorically to Jesus's crucifixion in John's gospel. On which, see John 12:23-28; 17:1; cf. 21:19. So also, Keener, pp. 728-729; J. Marcus, "Crucifixion as Parodic Exaltation," JBL 125 (2006), pp. 73-87.

63 If the reference to "water" activates the first manifestation of Nicodemus, ancient audiences might render "blood and water" as a reference to the end of Jesus's physical life (blood) and the continuation of his presence via the spirit (water) (see John 3:5-8; cf. 1.10-13). As Jesus nears death he tells bystanders that he is thirsty $(\delta i \omega \hat{\omega})$. Outside of his death, the verb only shows up in the dialogue with the Samaritan woman (John 4:13-15), the bread of life discourse (6:35), and his speech at the Festival of Sukkot (7:37-38). In each of these instances, "thirst" is linked to unmet desire (symbolized by the desire to drink), "drinking" to believing, and "water" to the Spirit. On "thirst" as a metaphor for desire, see Plato, Gorg. $496 \mathrm{e}-498 \mathrm{~b}$. 
which portrays Jesus's death as the ultimate failure of his own people (via physical generation) to accept him (1:11) and offers spiritual generation (via God's spirit at the glorification-crucifixion of Jesus) to all who receive him, frames Nicodemus's final appearance in John's gospel as one suggestive of spiritual birth (cf. 1:12-13; 3:1-10; 7:37-39).

(c) events After the Death Type Scene Frame: Attentive ancient audiences would recognize this scene as part of the standard "events after death" element prescribed for the composition of encomium, synkrisis, and diegesis, as, for example, the progymnasmata of Ps-Hermogenes (second century CE) recommends. ${ }^{64}$ The arrival of two men to retrieve the body of Jesus, one of whom is explicitly one of Jesus's "disciples," suggests that these men have some affinity for Jesus. That they request his body from the man who ordered his execution and that Nicodemus brings such an extravagant amount of burial spices creates the expectation that these men were close to Jesus. Furthermore, the traditional role that loved ones and other family usually played in funerals-absent here unless audiences so categorized Nicodemus (and Joseph) — ancient audiences would likely construe the men who retrieved the body and performed the simple but extravagant funeral as some of Jesus's closest companions. ${ }^{65}$

(d) BeREAVED COMPANion Character Type: The Bereaved COMPANION often accompanies the EVENTS AFTER THE DEATH type scene frame. Any number of the many extant literary examples of the BEREAVED COMPANION character type may inform audience impressions of the relationship between Jesus and Nicodemus. ${ }^{66}$ Such figures make demonstrations of their deep love for their deceased friend, whom they often grieve in intense and-by

64 "You will examine also events after death: if they held games in his honor, as for Patroclus; if there was an oracle about his bones, as with Orestes; if he had famous children, as did Neoptolemus" (Ps-Her Prog. 16-17). Arguably, events after death may be included in Aelius Theon's instruction to narrate the "good death" (Prog. 110). "Events after death" also feature in the biographies of Plutarch (Alcibiades 39.4a and Coriolanus 39.5-6), Philostratus (Vita Apollonii 8.31), and Philo (De vita Mosis 2.291b). On which, see M.W. Martin, "Progymnastic Topic Lists: A Compositional Template for Luke and Other Bioi?,” NTS 54 (2008), pp. 18-41.

65 See Plutarch, Alcibiades 39.4a; idem, Coriolanus 39.5-6; Philostratus, Vita Apollonii 8.31; and Philo, De vita Mosis 2.291b. Cf. Virgil Aen. 6.224-225; Ovid Metam. 2.626; Josephus, Ant. 17.199; J.W. 1.673; m. Ber. 8:6.

66 Cf. Achilles (mourning Patroclus); David (mourning Jonathan); Jesus (mourning Lazarus); and Phaedo, Crito, \& Apollodorus (mourning Socrates). 
modern standards - even theatrical or hyperbolic ways (see Figure 7 above). Likewise, we should assume that ancient audiences had their own experiences burying friends and family and will construe Joseph and Nicodemus as loving Jesus as they had loved their own departed.

(e) JohANNine Disciple Character Type: For many audience members who find themselves in the completion articulated this far, Nicodemus's behavior will activate the JOHANNINE DISCIPLE character type. ${ }^{67}$ Essentially, a JOHANNINE DISCIPLE has come to God's light and received the power for a spiritual generation (1:10-13). They continue in Jesus's teaching, set free by the truth of God's logos, to "follow me" (8:31-32; cf. 1:43; 8:12; 10:27; 12:26; 13:36; 21:19, 22). Their service to Jesus, or what Jo-Ann Brandt calls "expressions of fidelity," characterize the most exemplary disciples within John's narrative world. ${ }^{68}$ Nicodemus's actions in John 19:28-37 fit hand-in-glove with such expressions and would probably activate the JOHANNINE DISCIPLE character type. ${ }^{69}$ This frame adds considerable significance to (and provides an interpretive lens through which to view) Nicodemus's courage to "follow Jesus" to his actual cross to retrieve his body and lovingly bury it with such costly and high honor, risking his life and reputation in the process. ${ }^{70}$

67 Entire books have been written on the nature of discipleship in John, and I cannot do the topic justice in this context. I would encourage the interested reader to consult, most recently, M. Zhakevich, Follow Me: The Benefits of Discipleship in the Gospel of John (Minneapolis: Fortress, 2020). See also, R.M. Chennattu, Johannine Discipleship As a Covenant Relationship (Peabody: Hendrickson, 2005); C. Bennema, Mimesis in the Johannine Literature: A Study in Johannine Ethics (LNTS, 498; London: T\&T Clark, 2017); S. Brown and C.W. Skinner eds., Johannine Ethics: The Moral World of the Gospel and Epistles of John (Minneapolis: Fortress, 2017).

68 Brant, p. 288. As Brant points out, the disciples' desire to know the place where Jesus stays (1:38); they retrive food him, while he rests at Jacob's well (4:8) and encourage him to eat when they return (4:31). An entire town town invites him to stay with them (4:40). The disciples attempt to keep him from drowning by bringing him into the boat (6:21). Martha worries that the smell of Lazarus's decaying body will offend Jesus (11:39), and Mary cares for his tired feet (12:3).

69 For evidence of early Christian inferences that Nicodemus ultimately became a disciple of Jesus, see, e.g., the Gospel of Nicodemus and John Chrysostom (Hom. Jo. 24 [on 2:23-3:4]), who notes that, compared to his encounter with Jesus in John 3:1-10, Nicodemus acts more courageously in 7:50 and 19:39.

70 So also, Brant (p. 288) who notes Nicodemus's provision of an excessive amount of spices for Jesus's burial as a demonstration of the authenticity fo his discipleship (19:39). 
Whatever dissembling Nic A and Nic B undertook has given way to the courageous grief of someone who has lost the teacher they loved dearly. This completion stage of the blend decategorizes Nicodemus as a DISSEM BLER and recategorizes him as a JOHANNINE DISCIPLE and BEREAVED COMPANION. Bereft of his teacher, he did not abandon service to him, even at the risk of his own life, social capital, and resources. Nicodemus was faithful, even - perhaps especially_after Jesus's death.

(3) Elaboration: As audience members "run the blend," simulating the character imaginatively according to the inner logic of the narrative, I argue that many will continue to think of Nic $\mathrm{C}$ acting as a dear friend and bereaved disciple, not merely a pious Jew fulfilling the Law (cf. Deut 21:23). ${ }^{71}$ Along with Joseph, Nicodemus retrieves Jesus's body in the light of day and carries it to a nearby tomb. Such intimate and intense physical and emotional labor points to love not obligation. Even if some in the audience infer that Nicodemus provides Jesus a burial fit for a king, ${ }^{72}$ I argue that many will (also) make a more fundamental inference: any person who risks their life to retrieve the dead body of someone killed by the state and brings a nearly unheard of amount of spices for the funeral loves that person..$^{73}$ Audience members would likely draw upon their own experiences carrying a dead body as they run imaginative simulations of Nic C. As such, their simulation may lead them to think of Nicodemus and Joseph loving Jesus more than his mother, Mary Magdalene, and the beloved disciple do — at least within the narrative world of John's gospel. They may have been present at his execution, but they did not risk coming for his body.

While audience members likely initially categorized Nicodemus as a suspicious dissembling character in John 3 , that he departs the gospel performing the most intimate and selfless act of kindness - preparing his friend's body for burial—strongly encourages recategorization as a Johannine disciple who loved Jesus deeply. He used to be so concerned with physical generation, but now he has transcended birth from "blood or of the will of the flesh or the will of man," having received the "power to become one of God's children" via God's logos (1:12-13). He may have first come to Jesus under the cover of darkness, but in his final encounter with Jesus he showed that he had indeed "come to the

71 Contra, e.g., R.E. Brown, The Death of the Messiah: From Gethsemane to the Grave, a Commentary on the Passion Narratives in the Four Gospels (New York: Doubleday, 1994), pp. 1218, 1240.

72 Certainly, the Johannine Jesus is portrayed as a king in John 19 (cf. 19:3, 12, 14-15, 19, 21).

73 Naturally, these options are not mutually exclusive. 
light, so that it may be clearly seen that [his] deeds have been done in God" (3:21).

The characterization-as-blending approach proposed above shows how a dynamic processing model works. The characterization of a character's initial appearance starts with their actions and speech either triggering an initially category-based or personalization-based pathway for a reader. Subsequent appearances blend with the initial appearance in ways that confirm or challenge the initial categorization. In the subsequent appearance blends, cross-space mapping sets up a composition that yields confirmatory categorization, individuation, and/or recategorization in the completion and elaboration steps. It also extends the dynamic processing model by incorporating more recursivity into the processes and accounting for inferences about characters beyond anything explicit in the narrative in a more explicit and precise way. The printed text of John's gospel simply does not provide everything needed to account for such a reading. For any reading to take place, one must draw upon narrative frames, character types, type scenes frames, personal experiences, and a host of recursive processes that work synergistically to produce the mental model of, in this case, "Nicodemus in John," who may just be the Johannine disciple par excellence.

\section{Concluding Remarks}

A blending-based approach to characterization helps account for aspects of Nicodemus's character that, while not explicit, were likely implicit for ancient readers/hearers of John's gospel. This Blending approach above not only suggests that ancient audiences would probably tend toward constructing "Nicodemus" not in terms of cognitive (mis)understanding, but misdirected love, it also shows why this is the case. The changes in Nicodemus's love over his three appearances-evident through cross-space mapping-encourage readers to infer his ultimate spiritual birth and ponder their own. ${ }^{74}$ Just as God's logos spoke the world into being, so too did his rhetoric birth eternal life within Nicodemus (cf. 1:1-4; 11-13).

Representing characterization as blending is a messy business that moves us well beyond traditional linear interpretation of a character as "round" or

74 For more on the potential rhetorical effects of the characterization of Nicodemus, see Whitenton, Configuring Nicodemus, pp. 119-136. 
"flat" into the dynamic and multidimensional landscape of the narrative mind. Even so, the approach outlined above is necessarily a simplified representation of the processes that take place as a reader experiences a narrative in real-time and reflects on a character in light of the totality of the story. No model currently available can predict the intricacies of prior knowledge primed and activated during a narrative simulation. Yet, the blends in this article realistically represent the cognitive processes involved in constructing a recurring character. That is, a blending-based approach to characterization helps explain the mechanics behind the dynamic processing model's interplay between categorization (based on narrative frames, character types, and viable examples of relevant prior knowledge) and personalization (represented by the character's behavior and speech).

And yet questions remain. For example, how might audiences perceive "Nicodemus" if they only heard John $1-3$ ? Or John 3 in isolation from the Prologue? Or only John 7 ? Or only John 19 ? What if they only heard John 1-3 and John 19? Or what if they heard all three episodes but out of sequential order? We are, naturally, a long way from any notion of authorial intent, but a cognitive approach to characters, based in realism, ought to acknowledge the certainty of a multiplicity of possible textual experiences. In this essay, I have entertained only one such configuration, but answering the questions posed above would doubtless enhance, complicate, and challenge my work. Alas, articles can only be so long, and "what I have written I have written."

Cognitive research is a treasure chest full of potential for the study of early Christian narrative. Blending-based approaches, such as the one advocated here, could be readily adapted to accommodate recurring intertexts or metaphors. One might also combine blending with the study of emotional response to narrative to anticipate audience emotions to recurring narrative elements. The possibilities are seemingly endless. Regarding the study of characters, in particular, blending allows us to embrace the subjectivity of reading while offering a stable set of parameters to guide judgments about audience inferences, the interplay between distinct character manifestations, and the potential for character development. The result, I suggest, is a more dynamic, engaging, and (hopefully) faithful modeling of the characters we encounter in the New Testament and beyond. 